\title{
NEW RESEARCH TRENDS CONCERNING THE HISTORICAL RELATIONSHIP BETWEEN EGYPT AND MESOPOTAMIA*
}

\author{
Josué J. JusTEL** \\ Universidad de Alcalá
}

In loving memory of María José Rubio Fuentes.

\begin{abstract}
The aim of the article is to offer readers a list of aspects that recent historiography has worked on in respect of the relationships between Egypt and Mesopotamia through History. Thus, three studies are provided, one for each millennium BC, showing recent discoveries and research carried out during the last decade, and which are leading to a reinterpretation of the topic.
\end{abstract}

KEYWORDS: Aramaeans, Egypt, Jews, Mesopotamia, scribes.

RESUMEN: El propósito del artículo es ofrecer a los lectores un listado de aspectos que la historiografía más reciente ha trabajado en torno a las relaciones entre Egipto y Mesopotamia a lo largo de la Historia. De esta manera, se proporcionan tres estudios, uno por cada milenio a. C., que muestran descubrimientos recientes y la investigación llevada a cabo durante la última década, y que debería implicar una reinterpretación del tema en cuestión.

PALABRAS CLAVE: Arameos, Egipto, judíos, Mesopotamia, escribas.

* This paper has been written thanks to a Ramón y Cajal contract, granted by the Spanish Ministry of Economic Affairs and Competitiveness (ref. RYC2013-13817), and is the result of research project HAR2015-63716-P, also granted by the same institution and FEDER. This is a revised version of the talk I held at the Current Research in Egyptology congress in June 19, 2019 at the University of Alcalá (Spain); I am most grateful to R. Sánchez Casado and the other members of the organizing committee for their invitation to take part in such event. Of course, all shortcomings are mine alone.

** Correspondence to: Josué J. Justel, Universidad de Alcalá, Facultad de Filosofía y Letras, Departamento de Historia y Filosofía, calle Trinidad, 1 (28801 Alcalá de Henares-Spain) - josue.justel@uah.es - https://orcid.org/0000-0002-8269-0177.

How to cite: Justel, Josué J. (2020), «New research trends concerning the historical relationship between Egypt and Mesopotamia», Veleia, 37, 179-195. (https://doi.org/10.1387/veleia.21024).

Received: 17 july 2019; accepted: 10 march 2020.

ISSN 0213-2095 - eISSN 2444-3565 / (C) 2020 UPV/EHU

(c) (7) This work is under a license

Creative Commons Atribución 4.0 Internacional 


\section{INTRODUCTION}

The relationships between Egypt and Mesopotamia form an enthralling topic that, since the beginnings of their respective disciplines (Egyptology and Assyriology) in the 19th century, have focused a large part of historical debates. In addition, over the last few decades, new discoveries have been made and new publications produced, showing that that type of study will continue to provoke reactions in the scientific community.

In that regard, one of the problems is that Egyptology and Assyriology are often configured as closed disciplines. That leads to textual and archaeological discoveries in one field not being appreciated (i.e., they are usually completely ignored) by specialists in the other - with notable exceptions (e.g., Warburton 2007, Stevenson 2013). For that reason, it is necessary for there to be a periodic exchange of data and opinions between specialists.

In my case, I am an Assyriologist and my interests lie in cuneiform cultures, from both Mesopotamia and the Levant. In the next pages, I will present three topics that I personally consider worthy of mention, given the newness of the sources or of the studies, and given the important historical implications they represent for both Egypt and Mesopotamia. There is one per millennium: (1) the original influence of Mesopotamia in the first Egyptian cultures; (2) the importance of new discoveries, relating to concerning the Amarna letters, for our knowledge of the nature of the Egyptian occupation of Syria-Palestine during the Final Bronze Age; and (3) the nature and functioning of the Jewish or Jewish-Aramaean communities of Elephantine compared with those of Babylonia, in line with the discovery of numerous new cuneiform texts generated by the latter.

\section{Mesopotamian influences on Early Dynastic Egypt: a reappraisal}

The extent to which Mesopotamia, and more specifically the cultures of the south (i.e., Sumer), influenced the formation of the Egyptian state has been subject to debate since the start of Egyptology and Assyriology. This is not the place to evaluate those elements, above all because I am not a specialist in the fourth and third millennia, but I would like to highlight the following ideas.

1. Contact points have been observed since the 19th century excavations in Mesopotamia and Egypt, and it was presumed, by means of stratigraphic and chronological analyses, that those originating from the former passed on to those of the latter ${ }^{1}$. These contact points vary, but the most important were iconographic and architectural elements: the type of construction called panelled-façade found in the Egyptian tombs of the First, Second, and Third Dynasties had their parallels in Sumerian temples, clearly earlier in time, and in representations with identical iconography on seals found in Southern Mesopotamia $^{2}$. The phenomenon seems to have emerged from the Uruk culture from the end of the 4th millennium, spreading by land to the culture of Naqada III: seals and other imported objects from Southern Mesopotamia, and sometimes made in Egypt but with

1 See a recent and general study on the topic in Stevenson 2012 .
2 See, for example, Roaf 1990, 67-68, or Wilkinson 1999, 32-33, with bibliography. 
Mesopotamian motifs, appeared at that time in Egypt. Those types of imports were symbols of prestige for the Egyptian elite, according to traditional interpretation (Wilkinson 1999, 43). However, the most important parallel is undoubtedly the representation on rocks or knives, in Wadi Hammamat, of drawings of typical Uruk and Jemdet Nasr vessels in the immediately preceding period $^{3}$ (Fig. 1).

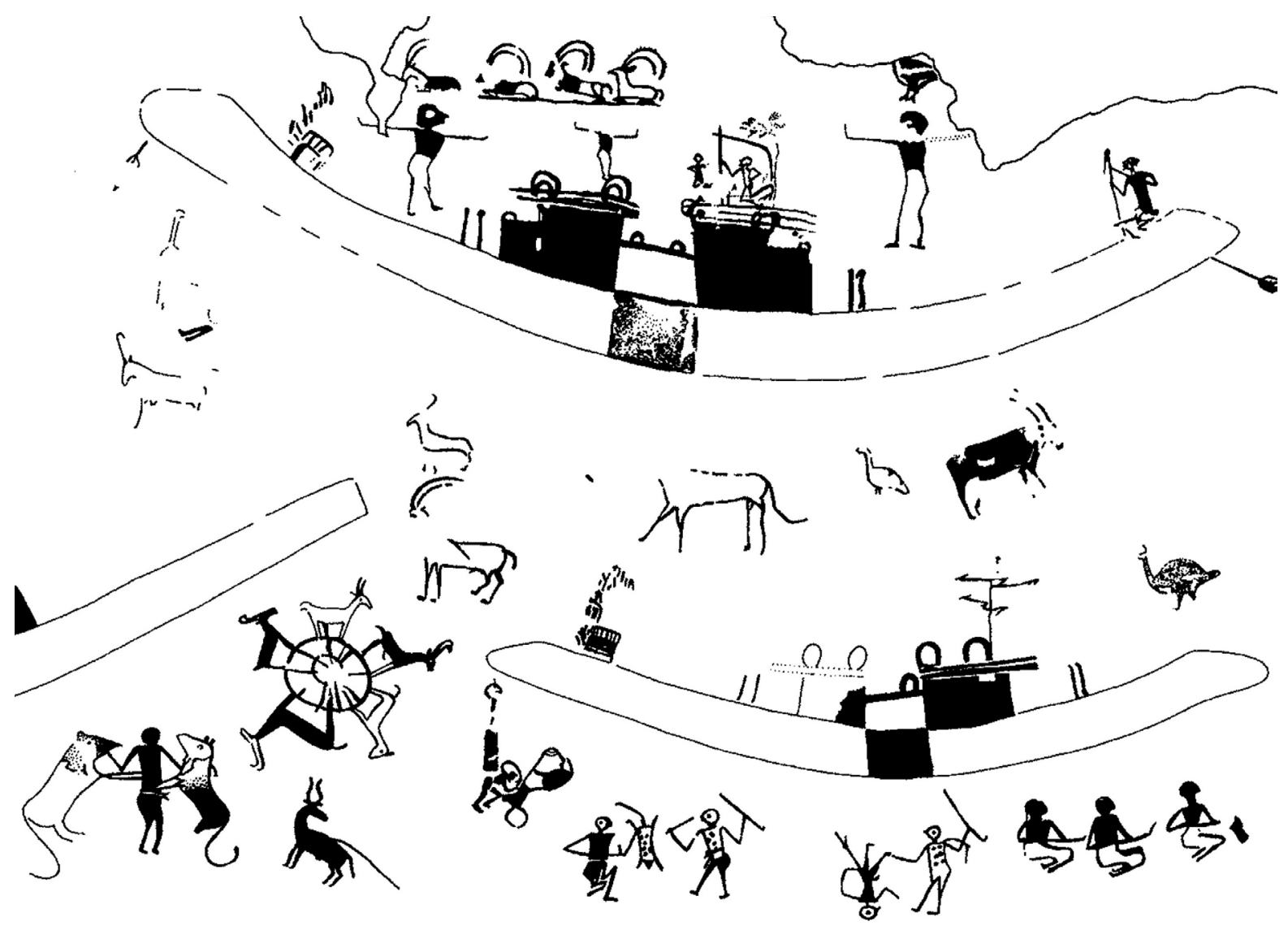

FIG. 1. Portion of a painted wall of tomb 100 at Hierakonpolis (Kemp 2006, 80)

2. However, new voices, above all of specialists in Egyptian archaeology from the 3rd millennium BC, tend to downplay those influences. In fact, the following has been indicated:

«Looking further afield, while various contacts with the Levant and Syria are clearly in evidence from Early Dynastic times and onward throughout the Old Kingdom, it seems that there were no direct contacts between Egypt and Mesopotamia during the 3rd millennium BC.» (Hikade 2012, 837).

3 Wengrow 2006, 40 and 136-140, with all the previous bibliography. 
In that vein, in contrast to what has often been presumed, it is not at all clear that the typically Mesopotamian cuneiform writing was prior to Egyptian writing or had any influence on it $^{4}$.

It is really not a question of downplaying Mesopotamian influences on the first Egyptian cultures, but of evaluating the degree of change that the former introduced to the latter. In the last general study on the topic, Stevenson $(2012,633)$ reviews all the currently available data, concluding that those influences did indeed take place, but that is is clear that any such influences were subject to local redefinition, resulting in a distinctly Egyptian material culture».

3. It has always been assumed that those first influences arrived by land, i.e., coming up from Uruk on the Euphrates and then going down towards the Palestinian coast and Egypt. However, there is still discussion about the sea links between Sumer and Egypt. Some authors think that it was not possible under any circumstances, due essentially to the enormous effort required to sail around the Arabian Peninsula (e.g., Wilkinson 1999, 170).

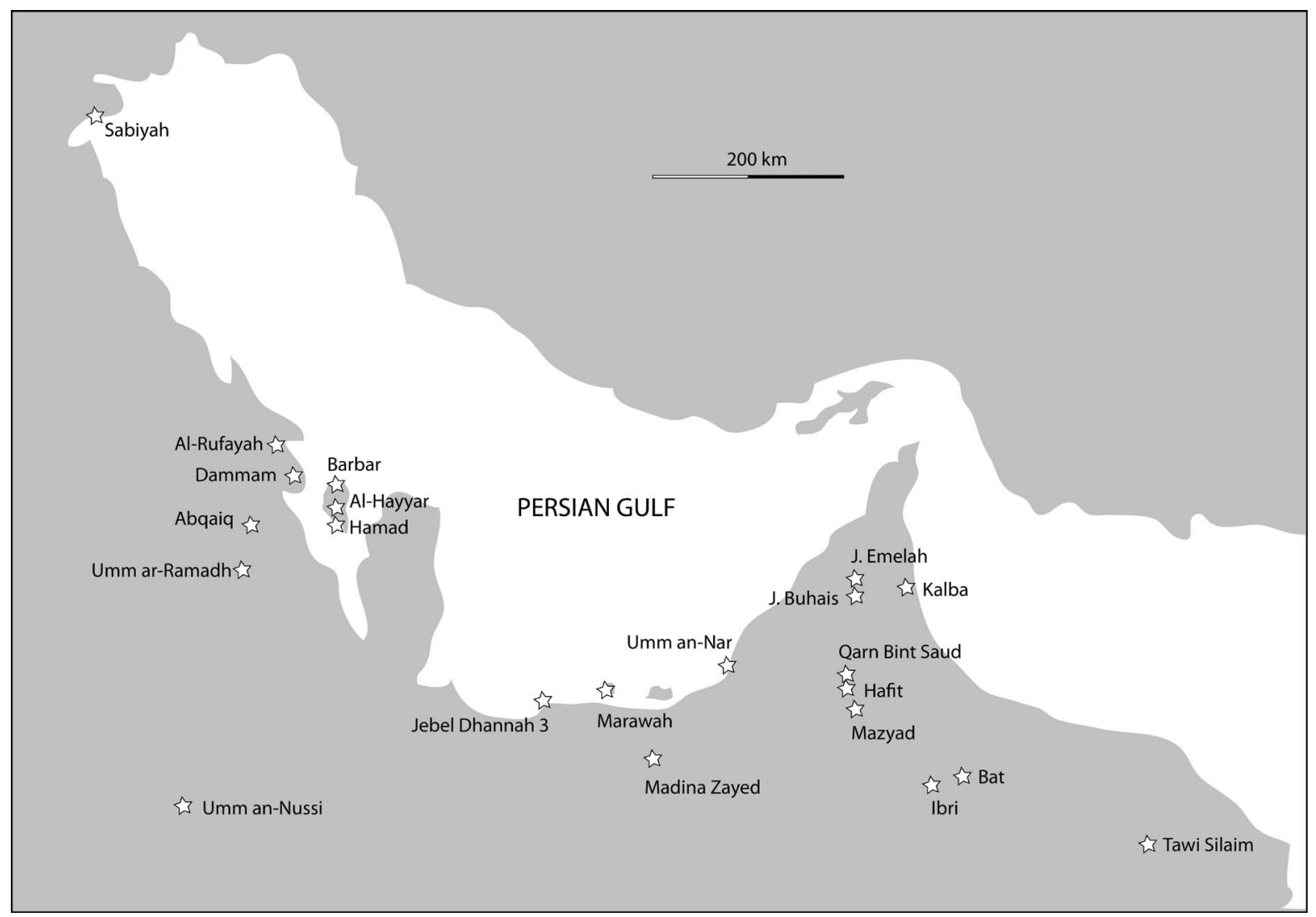

Fig. 2. Map of the Persian Gulf, with indication of sites of the sites with Mesopotamian finds of Late Uruk to Early Dynastic II date (after Carter 2013, 582).

4 See, for instance, Englund 1998, 79-80, and specially the clear statement of Cervelló Autuori 2005,
368-369; the latter author indicates that writing in Egypt developed independently. 
However, new archaeological data lead to reconsidering that situation. The data refer, above all, to new settlements discovered in the last decades in the eastern part of Oman, which would reveal the existence of communities that, seemingly, had direct contacts with other communities in Southern Mesopotamia 5 . With that, I also refer - among other facts - to new analyses of bronze products revealing that, in Uruk of the late third millennium, those tools were brought from some Omani $\operatorname{sites}^{6}$ (see Fig. 2).

It is possible, therefore, that the cultural and material expansion experienced by Mesopotamia during the time of Uruk at the end of the fourth millennium BC was not only directed towards the north and east-west, but also the south (see Thornton 2012) and, from there, to Egypt.

\section{The Egyptian occupation of the Levant DuRing the i4TH Century BC: SOME NEW ASPECTS}

As is well known, during the Late Bronze Age, Levantine territory was disputed by several powers: basically Egypt, Mitanni, and Hatti ${ }^{7}$. We all know that the balance of powers in the area was delicate and changing: Mittani's occupation of Northern Syria was followed by an increase in Egyptian hegemony during the 15 th century $\mathrm{BC}$, and finally, the control of that territory by the Hittite empire from the 13th century BC onwards. However, until the end of the 20th Dynasty (ca. 1110 BC), Egypt continued to control the southern Levantine strip (Murnane 1995, 708) (see Fig. 3).

We know quite a lot about the situation of the cities under Egyptian control during the first half of the 14 th century BC, thanks to the famous Amarna letters ${ }^{8}$. I will not emphasise the nature, composition, or importance of that archive, comprised of more than 360 cuneiform texts and found at the end of the 19th century in Amarna (ancient Akhetaten), capital of Pharaoh Amenhotep IV (Akhenaten). Essentially, the period covered by that body of texts is, at most, thirty years, between the reigns of Amenhotep III and IV (Moran 1992, xxxiv). Some of those letters are correspondence between the great powers of the time and Egypt: Assyria, Babylonia, Mittani, etc. Other letters, about 270, actually are correspondence between the small states and cities of the Levant, which were under Egyptian control, and the Pharaoh?

Over the last two decades - and especially during the last five years — new lines of research have been opened, or other lines have been fostered that, I believe, may be of interest to any scholar interested in the Ancient Near East and the phenomenon of cultural contacts in ancient societies. Basically, there are three aspects that enable us to analyse those letters from new perspectives: (1) the linguistic study of the content of the letters, a topic that I cannot go into in depth $^{10}$; (2) the petrographic analysis of the supports on which the missives are written ${ }^{11}$; $(3)$ the palaeographic analysis of the texts originating from the area under Egyptian control. The latter is, undoubtedly, the newest and more relevant, as I will now explain.

5 See, especially, Carter 2013, with all previous bibliography.

6 See, for example, the data presented in Begemann \& Schmitt-Strecker 2009 and Begemann et al. 2010.

7 Liverani 2001 and, specifically for the relationship between Mesopotamia and Egypt, Warburton 2007, 490-495.
8 The latest complete edition of these texts is to be found in Rainey 2015.

9 Liverani 1998; for other cuneiform texts of the time, which were not from Amarna, but found in the southern Levant, see Horowitz, Oshima \& Sanders 2018.

10 See bibliography presented in Vita 2015, 141-144.

11 Essentially presented in Goren, Finkelstein \& Na'aman 2004. 

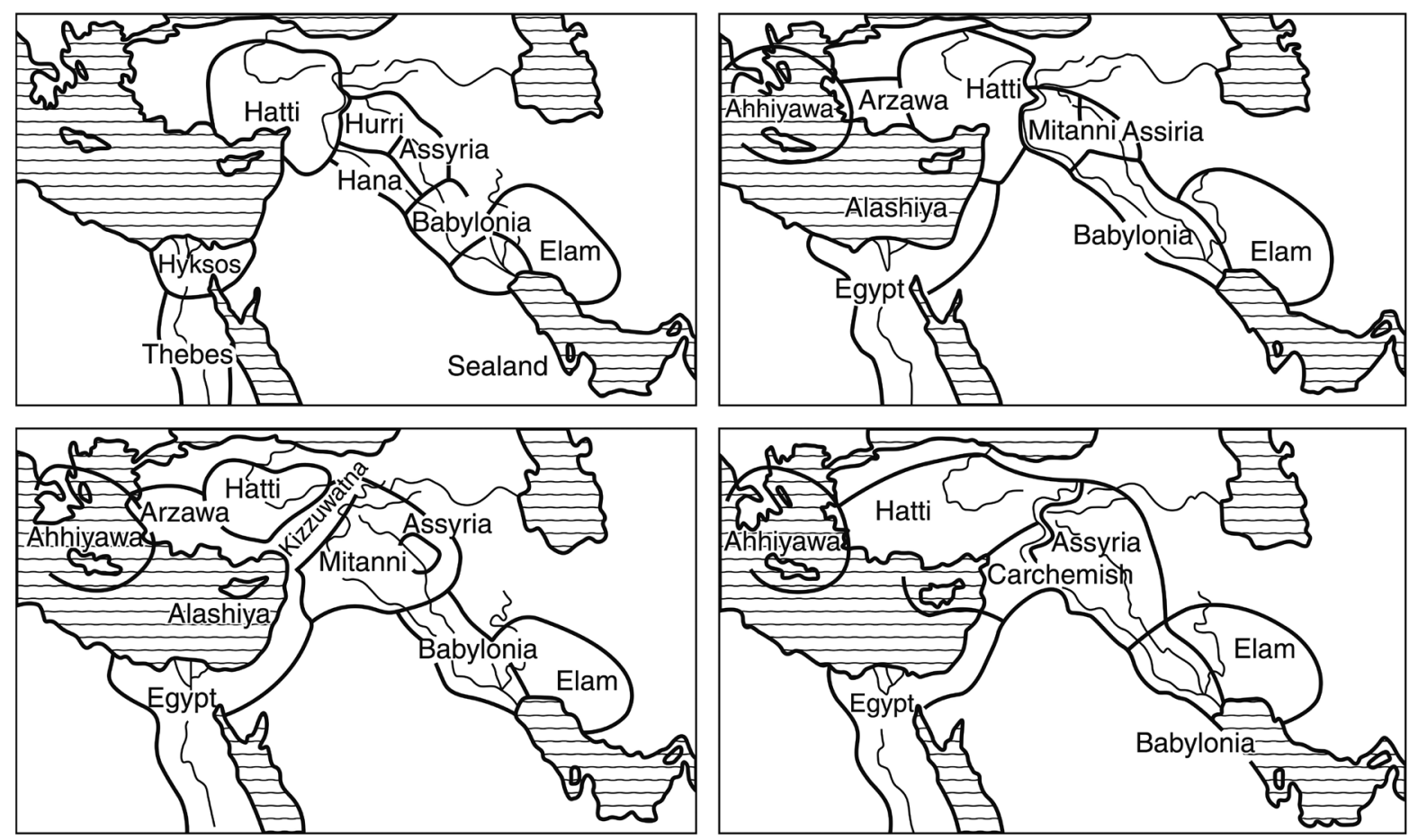

Fig. 3. The Ancient Near East during the Late Bronze Age (Liverani 2013, 279). Above, left: The formation period, ca. 1600 BC; below, left: The hegemony of Egypt and Mittani, ca. 1450 BC; Above, right: The hegemony of Egypt and Hatti, ca. 1350 BC; Below, right: The final stage, ca. 1220 BC.

Some years ago, now, the study of the «scribes' hands», namely the specific way in which each scribe wrote the same sign, became fashionable. That was applied to several areas and periods ${ }^{12}$. In the specific case of the Amarna letters, it is important to highlight the fact that they are never signed; in other words, there is no way of us knowing the scribes' names. Therefore, that line of research may potentially offer important historical results. The end - for the moment - of that work process was the publication of a book that contains the possible identifications of those scribes, in line with their ductus, petrographic analyses, and the specific writing dialect, as well as with the content of the text (Vita 2015).

Which conclusions, drawn from these works, may be relevant for historians of that period and area? The following, mainly:

1. One third of the letters found in Amarna are of unknown origin (Izre'el 1990, 592-597); indeed, we do not know the origin of 57 of the 268 letters from Syria or the Levant that are preserved in good condition (Vita 2015, 140).

2. Given that information, until now a certain Amarna letter was usually linked to a specific population, on the basis of its content. More recent philological, petrographic, and palaeographic research studies indicate that that criterion may lead to mistakes. By

12 As an example, Devecchi 2012, or the bibliography presented by Vita 2015, 6 . 
identifying the scribes, it has been possible to determine that a letter was written by the same scribe who wrote for other kings, for example (see Fig. 4).

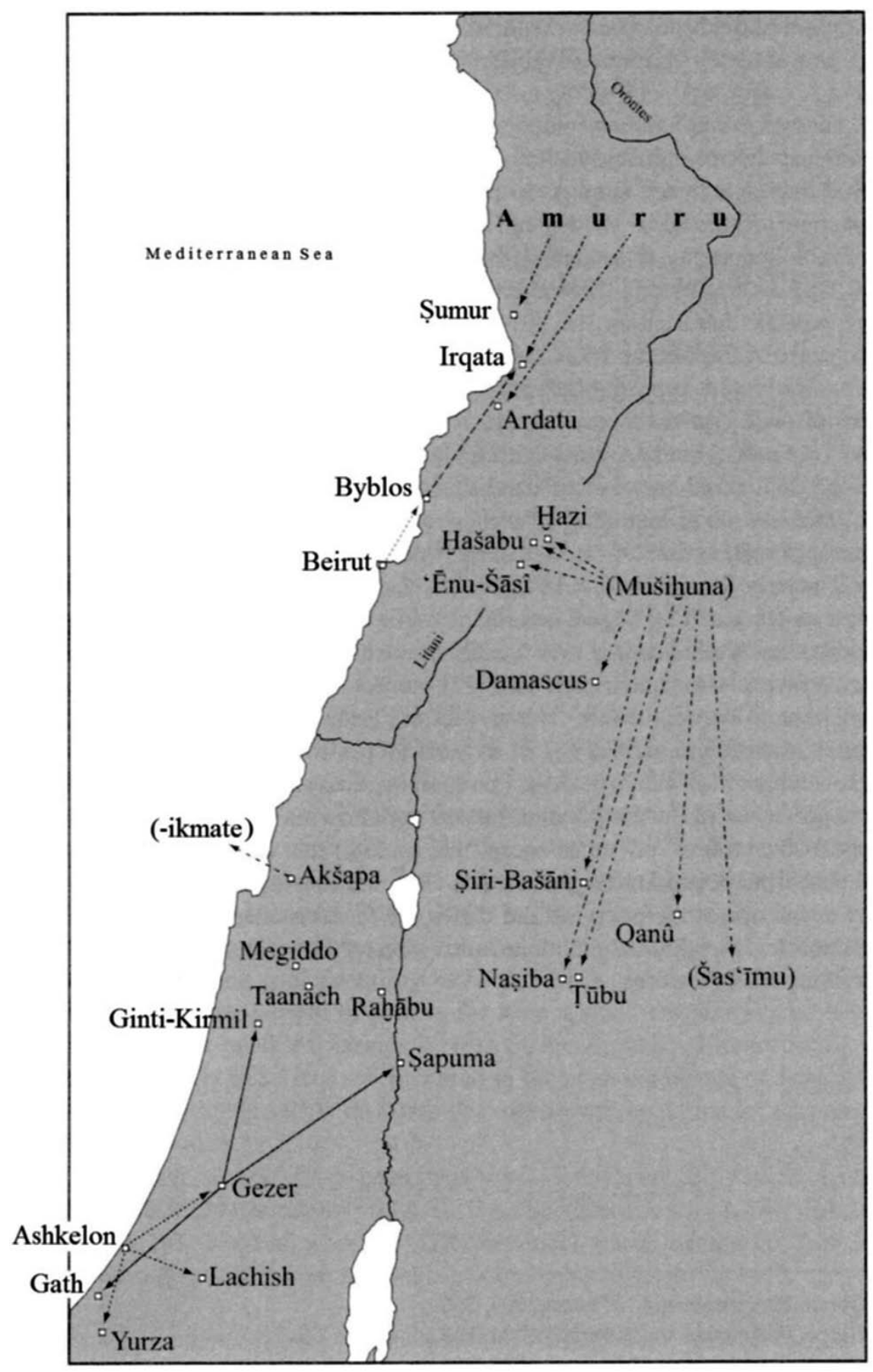

FIG. 4. Cities of the Levant, linked by scribes (Vita 2015, 150). 
3. Thus, from the historical viewpoint, any rectification may, in turn, lead to reinterpretations of considerable historical impact. One example will suffice, that of the missives of the Kingdom of Amurru, situated near the Orontes River ${ }^{13}$. Until not very long ago (Singer 1991, 143-145), based on letters EA 60-62 and EA 371, it was thought that King 'Abdi-aširta of Amurru had taken the cities of Ardatu, then Irqata, and finally Șumur, which was the Egyptians' base of operations in the area (see below). Now, with new research studies, we know that EA 60 and EA 371 were written by the same scribe in the area of Tripoli (Lebanon), and EA 61 and EA 62 were written by another scribe and sent from the city of Ardatu. For the moment, we can see that no letters were written in Sumur, the most important centre of the area, so the order of events must have been different from what we had thought until now. In a second phase in the history of Amurru, it had been interpreted (Singer 1991, 148-153) that the new king, Aziru, continued to conquer territories to the south, in the direction of Byblos, and conquering Ardatu, then toward the north, taking Irqata, and finally Șumur after besieging it for several months. Aziru would, therefore, have sent several letters to the Pharaoh before travelling to Egypt (EA 156-168, EA 171), during his stay in Egypt (EA 169-170), and after returning to Amurru (EA 161, EA 164-168). However, new research reveals something completely different. Aziru would have started to send letters to the Pharaoh after taking Ardatu and changing the capital of the kingdom to Irqata, and afterwards he sent missives from Șumur (EA 165-167) when travelling towards Egypt - in other words, he would not have sent them after his return. What is more, the meticulous analysis of the "scribes' hands» indicates that Aziru only had one scribe. That changed when Irqata became the capital of the Kingdom of Amurru, and from where he sent missives written by several scribes, which could reveal that the chancellery and the administration of the kingdom were undergoing expansion.

4. An important element when identifying scribes is being able to recognise that there were large administrations (e.g., Byblos, Amurru, and Gezer) that had several scribes, whilst there were some scribes who worked for several kings from different locations. That latter aspect is very important from the historical viewpoint and, according to Vita $(2015,145-149)$, the following situations can most likely be established:

- Cities that had good political relations, such as Gezer or Gath, could share scribes.

-A king could act as a host at diplomatic meetings and his scribes could write missives for each of the participants. That is the case, for example, of a Gezer scribe who wrote letters for the so-called "Beqa' alliance» (EA 275-278).

- One king could protect another king, who had been deposed and was in exile; the former's scribes could write missives for the latter.

- Scribes, apart from their activity for a specific king, could travel between cities and offer services there. There are several examples of that circumstance: probably EA 275-278, EA 291, etc.

- Finally, and perhaps most important of all, that information enables us to observe how the Egyptian administration operated in the area.

13 As explained in Vita 2015, 120-123. 
Regarding the latter topic, Egyptian control over this region was exerted from the six administrative centres, the most important, perhaps, being Gaza ${ }^{14}$. The analysis of the Amarna letters, in line with the new palaeographic, petrographic, and linguistic data, indicates that some of the letters, presumably sent from Gaza, could have been sent from other administrative centres: the origin of EA 298-300, EA 315, EA 378 could have been Ashkelon; EA 224, 232, 234-235, EA 285, etc., would have been sent from Bet-šean; EA 78, EA 103, EA 126, 165-167 from Șumur; etc. Likewise, we know now that some of the letters that we thought had been sent from other places came from Gaza (EA 168, EA 319). All of this information will, necessarily, entail historical reconsiderations with major consequences in the future.

\section{Elephantine and NeW discoveries about the lives of JeWs in Babylonia}

Our knowledge about the lives of the Jewish population between the 7 th and 5 th centuries BC is mainly based on three types of sources: Biblical, epigraphic / palaeographic, and archaeological. There are problems involving each one of them that cannot be discussed in depth here. In essence, Biblical documentation is usually accused of being partial and focused on very specific aspects relating to the experiences of Jews deported to Babylonia (i.e., Mesopotamia), and, above all, of reflecting the interests of specific social and theological groups ${ }^{15}$. In the case of archaeological sources, the last decades have witnessed an increase in studies that help to give us a better idea of what really occurred in the Palestinian area and the Levant during the time of the Exile and subsequent centuries ${ }^{16}$. Here we are interested in the extra-biblical written sources.

Those types of sources have, until now, been mainly the ostraca and papyrus from Biblical lands (especially Idumaea), as well as those found in Egypt. Undoubtedly, regarding the latter, worthy of note are the papyri of Elephantine, which tell about the life of a Jewish colony in Yeb / Elephantine, whose existence would date from at least the beginning of the 6th century BC and would last until beyond the 4th century $\mathrm{BC}^{17}$ (see Fig. 5). Until not very long ago, Elephantine in Egypt was our main source of (direct) information about the existence of Jewish communities outside Palestine: their cult, their intercultural relations, etc. Literature in that regard is extensive, after more than a century of research on the documents found there. However, there are still many doubts and open questions about different aspects of the life of that community ${ }^{18}$. One of the most relevant aspects, regarding which there is still no general consensus, is the date the Jewish community of Elephantine was established. In that regard, proposals go from the end of the 8th century BC, when the Assyrians occupied the area of the Levant (originally in Anneler 1912; on the context, Bagg 2011), until the beginning of the 6th century BC (especially, Porten 1968, 15) or the end of that century (e.g., Grelot 1972, 37, or Vittmann 1998, 89). The widespread view, most recently expressed by Porten (2003), places the establishment of this community at an earlier time, in the mid-7th century BC, and, therefore, before Josiah's religious reform took place

\footnotetext{
14 See, in general, Morris 2005, as well as the brief survey of Liverani 2005, 10-12.

15 See, as an introduction, Japhet 2003; 2006, with all the additional bibliography.

16 See, for example, in general, Finkelstein \& Silberman 2001, as well as articles with an archaeological
}

content in Lipschits \& Blenkinsopp 2003; Lipschits \& Oeming 2006.

17 See Porten 2011 as an updated introduction to the topic, with all the previous bibliography.

18 See recently, for example, Rohrmoser 2014. 
(2 Kings 22, 3-20); in fact, the cult to YHW carried out at his Elephantine temple seems to reflect pre-Exile practices (Rohrmoser 2014, 237).

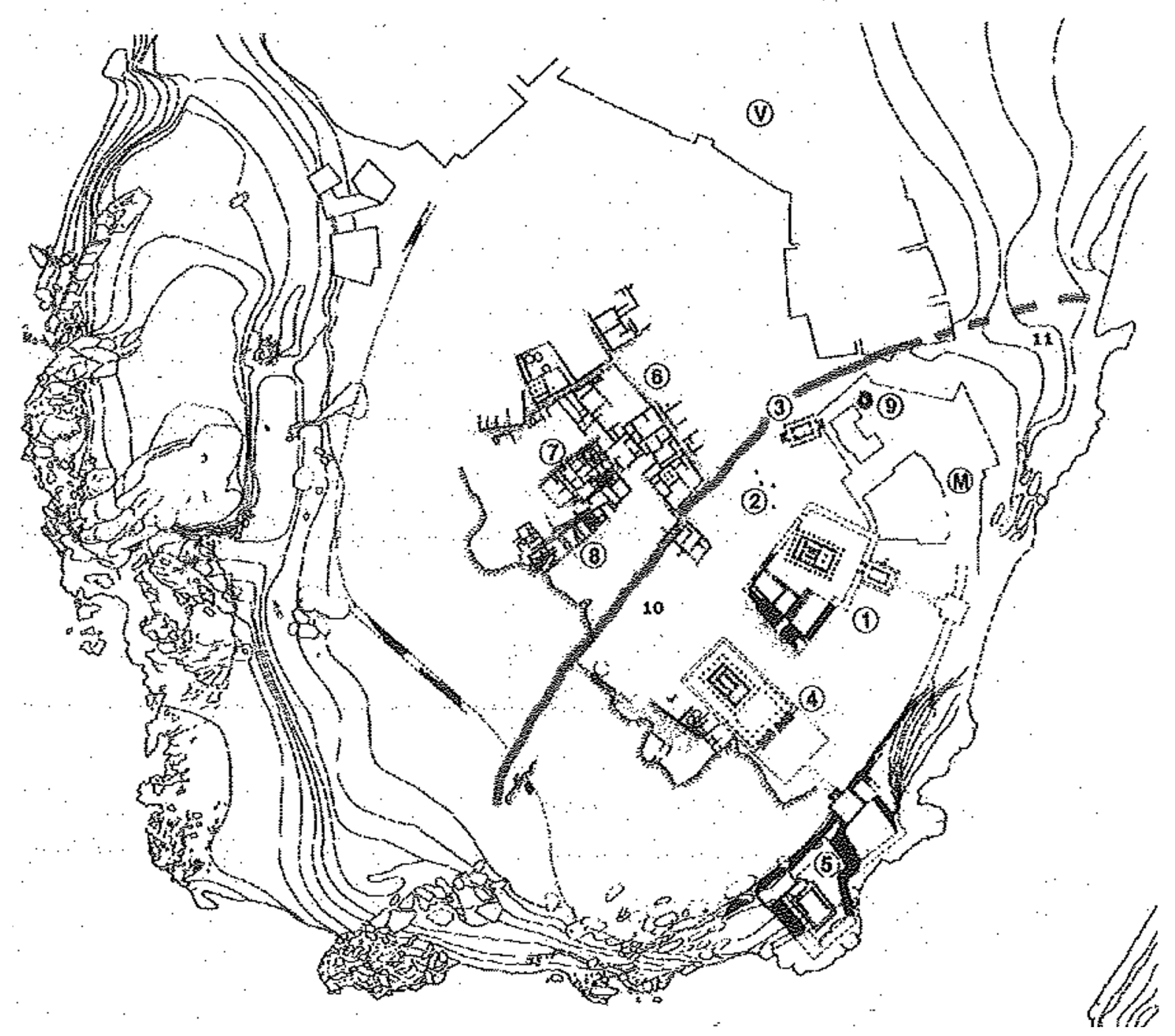

FIG. 5. Plan of the archaeological finds in Elephantine during the Persian period (Rohrmoser 2014, 45).

For its part, in Mesopotamia, admittedly, there was also an important Jewish community. They were a group of people deported from Palestine to Babylonia and nearby regions, firstly by the Assyrians (722 BC), and then by the Babylonians (597 and $586 \mathrm{BC}$ ). With the arrival of the Persians in $539 \mathrm{BC}$ and the so-called "permit» granted by Cyrus the Great in the following year, which would have allowed the Jewish people to return to their land (Ezra, 1, 1-4 and 6, 3-5), a considerable number of those deported remained in Mesopotamia. The presence of 
those Jews in cuneiform sources, above all from Southern Mesopotamia, was already known: a cuneiform document published in 1939 gave information about the food allowances by the Babylonian authorities to the Jewish leading class (Weidner 1939); and the royal inscriptions of Nebuchadnezzar refer to the conquest and deportations of those people (see esp. Pearce 2016, 232-233, with previous bibliography). Furthermore, as stated in the cuneiform archives of the Murašû family, natives of Nippur, Jews appeared quite frequently, i.e., people with clearly Jewish names ${ }^{19}$. However, in that archive - comprised of around 700 texts - Jews mainly appeared as witnesses of the different types of legal documents, not as stakeholders. Furthermore, those are also late sources, corresponding to the reigns of Artaxerxes I and Darius II - in essence, the second half of the 5th century BC. Fundamentally and simply, we had no knowledge of the internal lives of the Jewish communities of the area (Bickerman 1984, 350).

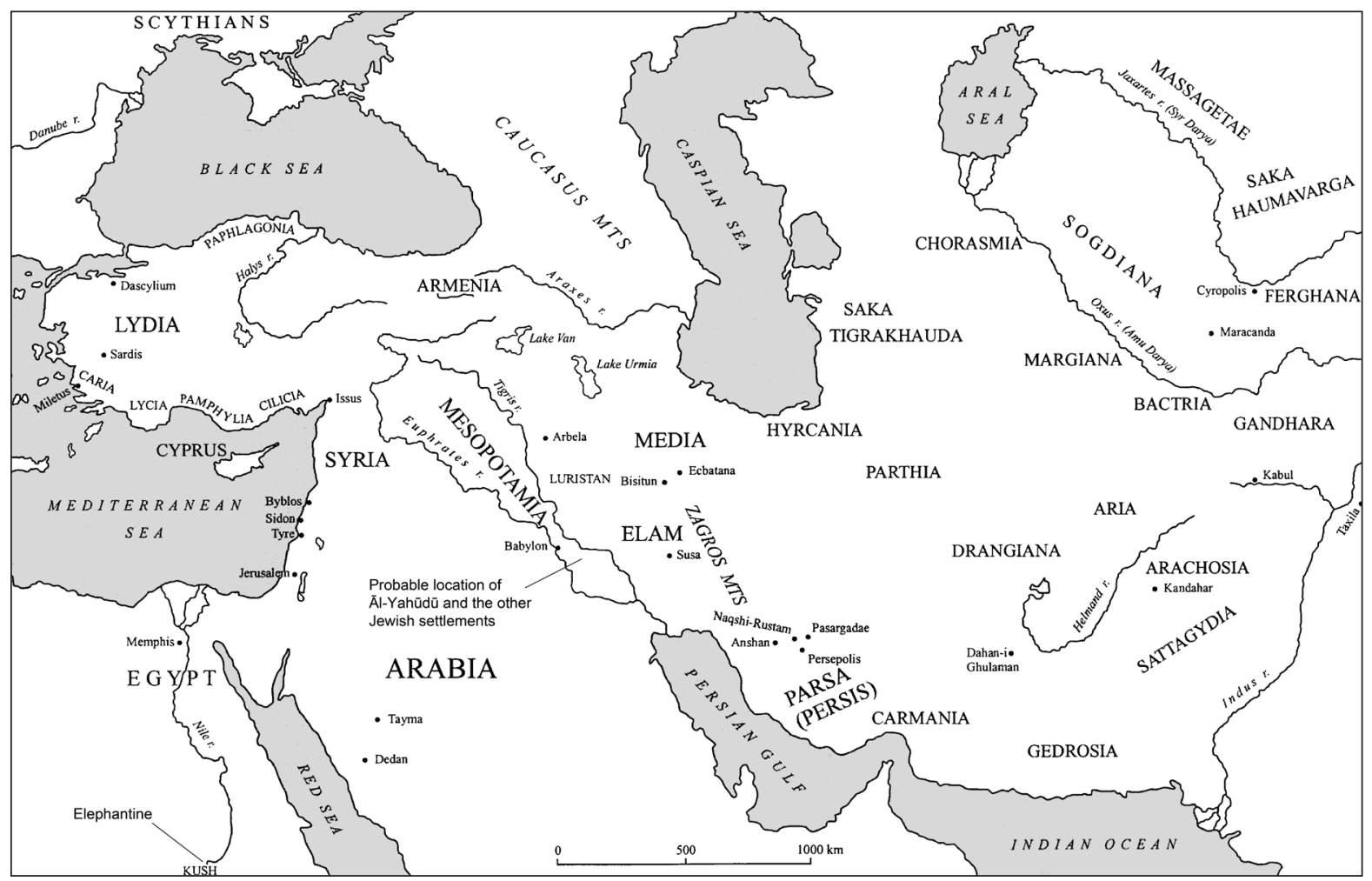

Fig. 6. The Ancient Near East during the Persian period, ca. 500-350 BC (after Bryce \& Birkett-Rees 2016, 544).

What is new at this point is the recent appearance of cuneiform documents from Southern Mesopotamia, discovered or published over the last few years ${ }^{20}$. That is a body of two hundred

19 See, especially Stolper 1985, and all the previous bibliography in Pearce 2014, 167-168.

20 From Joannès \& Lemaire 1996 to the main body in Pearce \& Wunsch 2014. There are still about one hundred, which will be published in the sixth volume of the series Babylonische Archive (ISLET, Dresden); and see additional bibliography in Pearce 2014, 165 n. 4. 
texts that have provided a lot of information about the lives of Jewish deportees in the country of Babylonia during and after the Exile ${ }^{21}$. Those cuneiform documents were written between 577 and 472 BC, and come from three different places: Āl-Yāhūdu (the majority), Ālu-ša-Našar / Bīt-Našar and Bît-Abī-râm; those would be locations near Borsippa or, more than likely, Nippur (Pearce \& Wunsch 2014, 6b-7a) (see Fig. 6, with indication of the site of Elephantine too). Unlike the texts originating from the Murašû family archives, the ones from those other three places directly involved Jews and other Aramaean populations, and not just as witnesses. Although only recently published, the content of all those documents has given rise to a good number of preliminary studies $^{22}$. Essentially, the importance of these cuneiform texts lies in that they are direct documents from the actual Jewish communities and very close in time to the start of the Exile.

How important is all of this for the topic of the contacts between Mesopotamia (i.e., Babylonia), the Levant and Egypt, which is what concerns us here? Basically, the following aspects, which I briefly set out below:

1. The Jewish communities, in both Babylonia and Elephantine, came directly from the Levant, although the first Assyrian deportations displaced people from the north (i.e., the Kingdom of Israel), and the later ones from the kingdom of Judah, that is, in the south. Basically, therefore, they were communities with similar origins.

2. The content of the Aramaean texts of Elephantine and the Akkadian texts of Babylonia complement each other considerably. In Elephantine, we find mainly private and public letters, as well as legal texts, on papyrus; in Babylonia, private legal texts on clay.

3. One of the most important elements, about which a lot has been written, is the personal names of the Elephantine Jews (see, in general, e.g., Zadok 1988). Approximately $25 \%$ of the personal names contain the theonym YHW, i.e., Yahu. What is most striking is the fact that, in personal names and references to God, there are only testimonies of the theonym YHW, and the use of the tetragrammaton YHWH does not appear - which does occur in the Old Testament (see, in general, Rechenmacher 2012, 205). This has led to a belief that the community would have originally come from Jerusalem or the surrounding area ${ }^{23}$. Until now, for the case of Babylonia, we did not have too much information about the personal names of non-Babylonian populations who were natives of the region and, also, urbanites (see Zadok 2003). The new documentation originating from the Jewish communities of Babylonia has obviously changed that panorama. What is interesting is that those sources show two elements:

- The percentage of proper names that contain the theonym Yahu seems to be higher than in the case of Elephantine. In any case, as in Elephantine, a good number of personal names show that the Jewish community were related to other populations, such as Elamites, Egyptians, etc. (Pearce \& Wunsch 2014: 11-15).

- The Jewish community from the exile in Mesopotamia did not use the tetragrammaton YHWH in personal names, either. They used YHW, with different spellings: $e-h u-u_{-}, i a-$ hu-ú-, -ia-a-ma, -i-ma-a, etc. ${ }^{24}$.

${ }^{21}$ About the identification of the Jews in these sources and their problems, see, especially, Pearce 2015.

22 For example, Pearce 2006; Magdalene \& Wunsch 2011; Wunsch 2013; Bloch 2014; Pearce 2014, 2015, 2016; Berlejung 2017; Hackl 2017, etc.

\footnotetext{
23 See, especially, the bibliographic notes of Rohrmoser 2014, 115.

${ }^{24}$ For a full range of attestations, see Pearce \& Wunsch 2014, 19-26.
} 
-Cuneiform writing may indicate, by means of a determinative, that what follows is interpreted as the name of a divinity. In the case of compound names with the theonym YHW, the determinative almost always appears when the theonym is in the initial position, and also in the texts of the first generation of deportees, ca. 577-550 BC (Pearce \& Wunsch 2014: 16b).

4. In Elephantine, there was a melting pot of cultures, and the Jewish community was simply another culture (see below). It must be observed that the community was not limited to a specific district, that is, it was not separated as if it were living in ghettos (Rohrmoser 2014, 101). There were intercultural marriages, too, which showed a mixed population ${ }^{25}$. It is also true that members of the Jewish community held posts of responsibility, but in general, of an internal nature. In the case of Babylonia, that was a very dynamic and multicultural society, too, above all due to the continuous passage of deported populations (see especially Zadok 2015). However, in line with the new discoveries, the situation of the Jewish community would have been completely different, in contrast to what has been considered until now: the integration of the Jews was quicker than was believed; they immediately started to occupy public posts of a certain responsibility in the machinery of the empire (first Babylonia, then Persia); and they were responsible for certain key commercial activities for the central state ${ }^{26}$. In addition, in Elephantine, the internal businesses of the Jewish community are well-known: buying and selling, lending, etc. We believe that the same occurred with the Jewish community of Babylonia; much of the documentation published to date concerns loans, rental agreements, exchanges, etc. ${ }^{27}$.

5. The existence, functioning, and other elements of the temple of the god YHW in Elephantine are well known, as are part of the priesthood and special elements of the cult ${ }^{28}$. It will be observed that in the new texts on the Babylonian Jewish community, reference is never made to an own temple in the region, or to personnel attached to it, or to specific religious practices. It is possible that that is due to the eminently administrative and legal nature of the cuneiform texts discovered, but it would also have been possible for Cyrus to have preferred new temples not to have been created, so centralising the cult in Jerusalem would help the Persian administration to control the occupied territories ${ }^{29}$.

6. A series of administrative and legal practices are observed in Elephantine and Babylonia that are worthy of attention. As indicated above, we have records of mixed marriages in Elephantine, that is between Jews and Gentiles, as well as inheritances and inter vivo transmissions ${ }^{30}$. We know perfectly well that the same occurred in the Jewish communities of Babylonia ${ }^{31}$.

7. Finally, it has been highlighted on many occasions that the Elephantine Aramaean papyri drew directly from the Mesopotamian legal tradition, and, more specifically, from Neo-

25 See the examples presented in Nutkowicz 2015, 29-30.

26 See a summary on the topic in Pearce 2006, 402403; 2014, 175-177; 2016, 233-234, with additional bibliography.

27 See the schema presented in Pearce \& Wunsch 2014, xxxvii. However, note that this view is not shared by other authors (e.g., C. Waerzeggers, in personal communication), and further research is still needed.
28 The most recent and complete study is by Rohrmoser 2014.

29 See, in that regard, the reflections of Bedford 2015.

30 See, most recently, the cases presented in Nutkowicz 2015, 29-30 and 217-239.

31 E.g., Abraham 2005-2006, 2007, 2015 (= CUSAS 28 45), with all the examples and bibliography. 
Assyrian customs ${ }^{32}$. The most recent research, however, clearly shows that Mesopotamian influences had to be adapted to the Egyptian social and legal context, a process in which the scribes played an essential role ${ }^{33}$. Something similar would have occurred in the case of the Jewish communities of Babylonia. The Jews in Babylonia did not learn to write cuneiform, and cases such as that of Daniel must be exceptional (see, for example, Stökl 2015). The Babylonian scribes identified the Jewish population as well as the problem of reflecting their personal names, and adapted their personal names to the cuneiform writing system ${ }^{34}$; in essence, the texts of the Jewish communities are typical of the Neo-Babylonian and Persian period. All that means that, in essence, the texts of the Jewish communities in Babylonia are typical of the Neo-Babylonian and Achaemenid period; essentially, we can trace no relevant idiomatic, social, or legal shift when the main parts of the documents were Jewish.

8. Finally, it is worthy of note that many of the texts relating to the Jewish communities of Babylonia focused their work on the lands that were distributed for use, that is, on life in the rural environment ${ }^{35}$. It has even been proposed, although no document explicitly indicates this, that those communities could have formed one of the hatrus of Persian times, which were no more than small-scale tax districts (Pearce 2006, 405; 2014, 177; 2016, 235). We do not find this phenomenon in the Elephantine sources, perhaps due to their specific nature or due to the socio-economic context when they were generated.

\section{BIBLIOGRAPHY}

Abraham, K., 2005-2006, «West Semitic and Judean Brides in Cuneiform Sources from the Sixth Century BCE. New Evidence from a Marriage Contract from Āl-Yahudu», Archiv für Orientsforschung 51, 198 219.

Abraham, K., 2007, «An Inheritance Division among Judeans in Babylonia from the Early Persian Period», in: M. Lubetski (ed.), New Seals and Inscriptions, Hebrew, Idumean and Cuneiform [Hebrew Bible Monographs 8], Sheffield: Sheffield Phoenix Press, 206-221.

Aвraham, K., 2015, "Negotiating Marriage in Multicultural Babylonia: An Example from the Judean Community in Āl-Yāhūdu», in: J. Stökl, C. Waerzeggers (eds.), Exile and Return. The Babylonian Context [Beihefte zur Zeitschrift für die Alttestamentliche Wissenschaft 478], Berlin \& Boston: De Gruyter, 33-57.

Anneler, H., 1912, Zur Geschichte der Juden von Elephantine, Bern: Drechsel.

BAGG, A., 2011, Die Assyrer und das Westland. Studien zur historischen Geographie und Herrschaftspraxis in der Levante im 1. Jt. v.u. Z. [Orientalia Lovaniensia Analecta 216], Leuven, Paris \& Walpole: Peeters, Department of Oriental Studies Leuven \& Louvain.

Bedford, P. R., 2015, "Temple Funding and Priestly Authority in Achaemenid Judah», in: J. Stökl, C. Waerzeggers (eds.), Exile and Return. The Babylonian Context [Beihefte zur Zeitschrift für die Alttestamentliche Wissenschaft 478], Berlin \& Boston: De Gruyter, 336-351.

Begemann, F., A. Hauptmann, S. Schmitt-Strecker \& G. Weisgerber, 2010, «Lead Isotope and Chemical Signature of Copper from Oman and its Occurrence in Mesopotamia and Sites on the Arabian Gulf Coast", Arabian Archaeology and Epigraphy 21, 135-169.

32 The book by Muffs 2003, originally published in 1968 , is still unchallenged in that regard; see p. XL-XLI.

33 See, in that regard, Botta 2009, esp. p. 200-203, with all the previous bibliography.
34 Pearce 2014, 181; Pearce \& Wunsch 2014, 15-16, 19, 24; Pearce 2015, 24, 26-28, 35.

35 See, for example, Pearce 2014, 173-175; 2016, 234-237. 
Bengemann, F., \& S. Schmitt-Strecker, 2009, «Über das frühe Kupfer Mesopotamiens», Iranica Antiqua 44, 1-45.

Berlejung, A., 2017, «Social Climbing in the Babylonian Exile», in: A. Berlejung, A. M. Maeir, A. Schüle (eds.), Wandering Arameans: Arameans Outside Syria. Textual and Archaeological Perspectives [Leipziger Altorientalische Studien 5], Wiesbaden: Harrassowitz, 101-124.

Bickerman, E. J., 1984, «The Babylonian Captivity», in: W. D. Davies, L. Finkelstein (eds.), The Cambridge History of Judaism. Volume One; The Persian Period Cambridge, New York \& Melbourne: Cambridge University Press, 342-358.

Bloch, Y., 2014, "Judeans in Sippar and Susa during the First Century of the Babylonian Exile: Assimilation and Perseverance under Neo-Babylonian and Achaemenid Rule», Journal of Ancient Near Eastern History 1, 119-172.

BоттA, A. F., 2009, The Aramaic and Egyptian Legal Traditions at Elephantine. An Egyptological Approach [Library of Second Temple Studies 64], London \& New York: T\&T Clark.

Bryce, T., \& J. Birkett-Rees, 2016, Atlas of the Ancient Near East. From Prehistoric Times to the Roman Imperial Period, Abingdon \& New York: Routledge.

Carter, R., 2013, "The Sumerians and the Gulf», in: H. Crawford (ed.), The Sumerian World, London \& New York: Routledge, 579-599.

Cervelló Autuori, J., 2015, Escrituras, lenguas y cultura en el Antiguo Egipto, Bellaterra: Servei de Publicacions de la Universitat Autònoma de Barcelona.

Devecchi, E. (ed.), 2012, Palaeography and Scribal Practices in Syro-Palestine and Anatolia in the Late Bronze Age. Proceedings of the International Symposium held in Leiden, December 17-18 [Publications de l'Institut Historique-Archéologique Néerlandais de Stamboul 119], Leiden: NINO.

Englund, R. K., 1998, «Texts from the Late Uruk Period», in: J. Bauer, R. K. Englund, M. Krebernik (eds.), Mesopotamien: Späturuk-Zeit und Frühdynastische Zeit [Orbis Biblicus et Orientalis 160/1], Universitätsverlag \& Vandenhoeck Ruprecht, 15-233.

Finkelstein, I., \& N. A. Silberman, 2001, The Bible Unearthed. Archaeology's New Vision of Ancient Israel and the Origins of Its Sacred Texts, New York: Free Press.

Goren, Y., I. Finkelstein \& N. Na'aman, 2004, Inscribed in Clay. Provenance Study of the Amarna Tablets and Other Ancient Near Eastern Texts [Monograph Series of the Sonia and Marco Nadler Institute of Archaeology Series 23], Tel Aviv: Emery and Claire Yass Publications in Archaeology.

Grelot, P., 1972, Documents araméens d'Égypte [Littératures Anciennes du Proche-Orient 5], Paris: Cerf.

Hackl, J., 2017, «Babylonian Scribal Practices in Rural Contexts: A Linguistic Survey of the Documents of Judean Exiles and West Semites in Babylonia (CUSAS 28 and BaAr 6)», in: A. Berlejung, A. M. Maeir, A. Schüle (eds.), Wandering Arameans: Arameans Outside Syria. Textual and Archaeological Perspectives [Leipziger Altorientalische Studien 5], Wiesbaden: Harrassowitz, 125-140.

Hikade, T., 2012, "Egypt and the Near East», in: D. T. Potts (ed.), A Companion to the Archaeology of the Ancient Near East Malden, Oxford \& Chichester: Blackwell, 833-850.

Horowitz, W., T. Oshima \& S. Sanders, 2018, Cuneiform in Canaan. The Next Generation, University Park: Eisenbrauns.

Izre'el, S., 1990, «A New Translation of the Amarna Letters», Bibliotheca Orientalis 47, 577-604.

Japhet, S., 2003, "Periodization: Between History and Ideology. The Neo-Babylonian Period in Biblical Historiography», in: O. Lipschits, J. Blenkinsopp (eds.), Judah and the Judeans in the Neo-Babylonian Period, Winona Lake: Eisenbrauns, 75-89.

Japhet, S., 2006, «Periodization between History and Ideology II: Chronology and Ideology in EzraNehemiah», in: O. Lipschits, M. Oeming (eds.), Judah and the Judeans in the Persian Period, Winona Lake: Eisenbrauns, 491-508.

Joannès, F., \& A. Lemaire, 1996, "Contrats babyloniens d'époque achéménide du Bît-abî Râm avec une épigraphie araméenne», Revue d'Assyriologie et d'Archéologie Orientale 90, 41-60.

Kemp, B., 2006, Ancient Egypt. Anatomy of a Civilization, second edition, London: Routledge. 
Lipschits, O., \& J. Blenkinsopp (eds.), 2003, Judah and the Judeans in the Neo-Babylonian Period, Winona Lake: Eisenbrauns.

Lipschits, O., \& M. Oeming (eds.), 2006, Judah and the Judeans in the Persian Period, Winona Lake: Eisenbrauns.

Liverani, M., 1998, Le lettere di el-Amarna. 1. Le lettere dei «Piccoli Re» [Testi del Vicino Oriente antico 3/1], Brescia: Paideia.

Liverani, M., 2001, International Relations in the Ancient Near East, 1600-1100 BC, New York: Palgrave.

Liverani, M., 2005, Israel's History and the History of Israel, London \& Oakville: Equinox.

Liverani, M., 2013, The Ancient Near East. History, Society and Economy, London \& New York: Routledge

Magdalene, F. R., \& C. Wunsch, 2011, "Slavery between Judah and Babylon: The Exilic Experience», in: L. Culbertson (ed.), Slaves and Household in the Near East [Oriental Institute Seminars 7], Chicago: University of Chicago, 113-134.

Moran, W. L., 1992, The Amarna Letters, Baltimore: The Johns Hopkins University Press.

Morris, E. F., 2005, The Architecture of Imperialism. Military Bases and the Evolution of Foreign Policy in Egypt's New Kingdom [Probleme der Ägyptologie 22], Leiden \& Boston: Brill.

Muffs, Y., 2003, Studies in the Aramaic Legal Papyri from Elephantine, with Prolegomenon by Baruch A. Levine [Handbuch der Orientalistik 66], Leiden \& Boston.

Murnane, W. J., 1995, «The History of Ancient Egypt: An Overview», in: J. M. Sasson (ed.), Civilizations of the Ancient Near East, New York: Charles Scribner's Sons, 691-717.

Nutkowicz, H., 2015, Destins de femmes au Ve siècle avant notre ère, Paris: L'Harmattan.

Pearce, L. E., 2006, «New Evidence for Judeans in Babylonia», in: O. Lipschits, M. Oeming (eds.), Judah and the Judeans in the Persian Period, Winona Lake: Eisenbrauns, 399-411.

Pearce, L. E., 2014, "Continuity and Normality in Sources Relating to the Judean Exile», Hebrew Bible and Ancient Israel 3, 163-184.

Pearce, L. E., 2015, «Identifying Judeans and Judean Identity in the Babylonian Evidence», in: J. Stökl, C. Waerzeggers (eds.), Exile and Return. The Babylonian Context [Beihefte zur Zeitschrift für die Alttestamentliche Wissenschaft 478], Berlin \& Boston: De Gruyter, 7-32.

Pearce, L. E., 2016, «Cuneiform Sources for Judeans in Babylonia in the Neo-Babylonian and Achaemenid Periods: An Overview», Religion Compass 10, 230-243.

Pearce, L. E., \& C. Wunsch, 2014, Documents of Judean Exiles and West Semites in Babylonia in the Collection of David Sofer [Cornell University Studies in Assyriology and Sumerology 28], Bethesda: CDL Press.

Porten, B., 1968, Archives from Elephantine: The Life of an Ancient Jewish Military Colony, Berkeley: University of California Press.

Porten, B., 2003, "Settlement of the Jews at Elephantine and the Arameans at Syene», in: O. Lipschits, J. Blenkinsopp (eds.), Judah and the Judeans in the Neo-Babylonian Period, Winona Lake: Eisenbrauns, 451-470.

Porten, B., 2011, The Elephantine Papyri in English. Three Millennia of Cross-Cultural Continuity and Change. Second Revised Edition [Documenta et Monumenta Orientis Antiqui 22], Atlanta: SBL.

Rainey, A. F., 2015, The El-Amarna Correspondence. A New Edition of the Cuneiform Letters from the Site of El-Amarna based on Collations of all Extant Tablets [Handbuch der Orientalistik 110], Leiden \& Boston: Brill.

Rechenmacher, H., 2012, Althebräische Personennamen [Lehrbücher orientalischer Sprachen II/1], Münster: Ugarit-Verlag.

RoAf, M., 1990, Cultural Atlas of Mesopotamia and the Ancient Near East, Abingdon: Andromeda.

Rohrmoser, A., 2014, Götter, Tempel und Kult der Judäo-Aramäer von Elephantine. Archäologische und schriftliche Zeugnisse aus dem perserzeitlichen Ägypten [Alter Orient und altes Testament 396], Münster: Ugarit-Verlag.

Singer, I., 1991, "A Concise History of Amurru», in: S. Izre'el (ed.), Amurru Akkadian: A Linguistic Study, vol. 2 [Harvard Semitic Studies 41], Atlanta: Scholars Press, 135-195. 
Stevenson, A., 2013, «Egypt and Mesopotamia», in: H. Crawford (ed.), The Sumerian World, London \& New York: Routledge, 620-636.

SтӧKL, J., 2015, “A Youth Without Blemish, Handsome, Proficient in all Wisdom, Knowledgeable and Intelligent": Ezekiel's Access to Babylonian Culture», in: J. Stökl, C. Waerzeggers (eds.), Exile and Return. The Babylonian Context [Beihefte zur Zeitschrift für die Alttestamentliche Wissenschaft 478], Berlin \& Boston: De Gruyter, 223-252.

Stolper, M., 1985, Entrepreneurs and Empire: The Murašûu Archive, the Murašû Firm, and Persian Rule in Babylonia [Publications de l'Institut Historique-Archéologique Néerlandais de Stamboul 54], Leiden: NINO.

Thornton, C. P., 2013, «Mesopotamia, Meluhḩa, and Those in Between», in: H. Crawford (ed.), The Sumerian World, London \& New York: Routledge, 600-619.

Vita, J. P., 2015, Canaanite Scribes in the Amarna Letters [Alter Orient und altes Testament 406], Münster: Ugarit-Verlag.

Vittmann, G., 1998, Ägypten und die Fremden im ersten vorchristlichen Jahrtausend [Kulturgeschichte der antiken Welt 37], Mainz: Phillip von Zabern.

Warburton, D. A., 2007, «Egypt and Mesopotamia», in: G. Lieck (ed.), The Babylonian World, London \& New York: Routledge, 487-502.

Weidner, E., 1939, "Jojachin, König von Juda, in babylonischen Keilschrifttexten», in: Mélanges syriens offerts à monsieur René Dussaud: secrétaire perpétuel de l'Académie des inscriptions et belles-lettres, Paris: Geuthner, 923-935.

Wengrow, D., 2006, The Archaeology of Early Egypt, Cambridge: Cambridge University Press.

Wilkinson, T. A. H., 1999, Early Dynastic Egypt, London \& New York: Routledge.

Wunsch, C., 2013, "Glimpses on the Lives of Deportees in Rural Babylonia", in: A. Berlejung, M. P. Streck (eds.), Arameans, Chaldeans, and Arabs in Babylonia and Palestine in the First Millennium B.C. [Leipziger Altorientalische Studien 3], Wiesbaden: Harrassowitz, 247-260.

Zadok, R., 1988, The Pre-Hellenistic Israelite Anthroponymy and Prosopography [Orientalia Lovaniensia Analecta 28], Leuven: Peeters.

ZadoK, R., 2003, "The Representation of Foreigners in Neo- and Late-Babylonian Legal Documents (Eighth through Second Centuries B.C.E.)", in: O. Lipschits, J. Blenkinsopp (eds.), Judah and the Judeans in the Neo-Babylonian Period, Winona Lake: Eisenbrauns, 471-589.

ZadoK, R., 2015, "West Semitic Groups in the Nippur Region between c. 750 and 330 B.C.E.», in: J. Stökl, C. Waerzeggers (eds.), Exile and Return. The Babylonian Context [Beihefte zur Zeitschrift für die Alttestamentliche Wissenschaft 478], Berlin \& Boston: De Gruyter, 94-156. 